\title{
FEMALE NARRATIVES OF LOSS: MEMORIES OF PARTITION
}

\author{
Carmen Escobedo de Tapia \\ Universidad de Oviedo
}

\section{Abstract}

The Indian English narrative has to be considered from a threefold perspective: history, nation and narration. Indian women writers have also tackled this theme. The way they represent the shock of Partition is very much related with the situation of women in India. This article aims to diacronically analize some examples of female Indian narrative: Sunlight on a Broken Column (1961) by Attia Hosain, Clear Light of Day (1980) by Anita Desai and An Unrestored Women (2016) by Shobha Rao, to specifically focus on how women characters build up their memories of the historical event as a narrative of loss through which, eventually, we can identify the trace of gender violence as linked to the concept of nationalism in an attempt to restore the past and the present.

Keywords: Cultural Studies, Gender violence, Indian narrative in English, Partition, Postcolonialism, Transglobality.

\section{RESUMEN}

La narrativa india en inglés precisa un análisis desde tres perspectivas íntimamente relacionadas: historia, nación y narración. Las autoras indias también han tratado este tema. La forma en que representan el trauma de la Partición está directamente relacionado con la situación de la mujer india. Este artículo analiza diacrónicamente algunos ejemplos de esa narrativa: Sunlight on a Broken Column (1961) de Attia Hosain, Clear Light of Day (1980) de Anita Desai y An Unrestored Woman (2016) de Shobha Rao, centrándose en cómo los personajes principales femeninos construyen sus recuerdos del acontecimiento histórico como una narrativa de pérdida. A través de la narración se identifica cómo la violencia de género se relaciona con el concepto de nacionalismo, en un intento de restaurar el pasado y el presente.

Palabras clave: Estudios Culturales, Narrativa india en inglés, Partición, Poscolonialismo, Transnacional, Violencia de género. 
Even today there is no peace. No peace outside, no peace inside. There is no peace even today. I don't sleep, there is a feeling of being unsettled. My daughters are also not at peace. There is no well- being.

Somavanti

...but hearing oftentimes

The still, sad music of humanity. William Wordsworth

Unfortunately, the time is ripe to rethink past traumatic episodes like the Partition of the Indian subcontinent. Seventy years have passed and the effects caused by this episode seem to have repercussion at this moment in the history of both the western and eastern worlds. The historical background of current times, the move towards new ways of radical nationalisms, the religious confrontations and fundamentalisms that have led to international terrorism, make it necessary to look back on the past in an attempt to hopefully search for restoration of the present. There is an objective political history and events that led to the 'Indian summer' as Alex Von Tunzelmann terms that season of 1947: "on a warm summer night in 1947, the largest Empire the world has ever seen did something no empire had done before. It gave up" (3). "Midnight's furies" were unleashed and gave rise to "the deadly legacy of India's Partition" (Hajari 2015).

But there are are also hidden stories behind the great names of the Partition, names like Gandhi, Jawarhalal Nehru, Ali Jinnah, Winston Churchill, Dickie Mountbatten and his wife Edwina. The truth that lies behind the real history nobody can know, but what is true is that the Partition is a story of violence and loss. While India and Pakistan gained Independence, the British Empire lost its greatest colony, Gandhi lost his dream of achieving a united nation that would gather Muslims and Hindus, and the first leader of democratic India, Jawaharlal Nehru, felt that all his dreams of life and freedom had turned into chaos and destruction:

Millions of people would be displaced; millions would be wounded; hundreds of thousands, perhaps millions more, would die. During the next few days, riots would spread across the divided states of the Punjab and Bengal, and a holocaust would begin (Von Tulzemann 7).

Heroism and incompetence caused one of the major holocausts in the twentieth century. The days of British splendour were gone, the great names were put to the margins and the margins came to the fore. The personal stories of the common people began to be considered.

In the 1970s the rise of the social history in the west, buoyed by structuralist arguments of the Marxists and Braudelians, forced historians to shift their gaze from the men in the corridors of power to the nameless and faceless common people, men and women. The new millenium has produced some innovative studies in the Partition history (Kaushik 2014). It is in this new social framework that women appear on the scenery of Partition as a subaltern group and with specific ways of having experienced the episode. 
Parallel to the political negotiations that took place over the years and that ended up in the tragic outcome, there was a movement among women pushed by Kamala Nehru, who had married the Indian leader and "who thought little of meek obedience and still less of pretty ignorance" (Von Tulzemann 70). She had married Nehru when she was seventeen, and, though being barely educated, she devoted herself to the cause of women pushing forward their fight for rights, education and struggle for their independence in the patriarchal society of the subcontinent. This was later undertaken by Edwina Mountbatten, who called for the emancipation of women despite the backwardness of the country, the illiteracy rate and the low standards of living. So women acquired an active role in the political sphere when the country was getting ready for Independence. But these efforts were unsuccessful, and, even more, women were the group that was most violently affected by the horror of Partition, which somehow was connected with the social reality of women in the subcontinent: "As always there was widespread sexual savagery: about 75,000 women are thought to have been abducted and raped by men of religions different from their own (and indeed sometimes by men of their own religion)." (Butalia 3).

Therefore, despite the efforts made by great public women previous to the Partition, the stories of women that were affected by the historical episode are also stories of loss, because reality shuttered their dreams to achieve any possible expectation in the aftermath of Partition. These stories are those of women who suffered silently, and who, still today, have not conquered spaces of freedom as human beings. They live on the other side of silence.

However, the partition of India is much more than just a historical fact (see Ahmed 2012; Nair 2011; Chester 2009). It is a compelling literary theme that still today continues to inspire creative outpourings by writers. History and na(rra)tion intermingle. Perhaps this is both an attempt to overcome the tremendous trauma created by Partition, and to bear witness to the forces of communalism, class divide and patriarchy behind the violent division, which continue to play out across the Indian subcontinent today and even throughout the world in different, subtle ways. Literature serves the purpose to reflect such terrible episodes in the history of humankind. By re-reading the past horrors of our history we can maybe shed light to hidden clues of understanding among us in our contemporary times.

Thus, the theme of Partition has inspired many Indian writers and has been tackled from many different perspectives, both in the corpus of Indian literature and Indian English narrative. Representative examples would be novels like Train to Pakistan (1956) by Khuswant Singh; Tamas (1974) by Bhisham Sahni; Midnight's Children (1981) by Salman Rushdie; short stories like "Toba Tek Singh" (1955) by Saadat Hasan Manto; and poems like those of Faiz Ahmad Faiz, who has also lamented the holocaust, in Subh-e-Azadi (Freedom's Dawn, 1974).

When approaching the contemporary Indian English novel we have to depart from the idea of India as "a paradigmatic example of [...] 'an imagined community' whereby large numbers of people come together to consitute that political and cultural entity known as 'the nation"' (Gopal 11). Consequently, the Indian English novel has to be approached from a threefold perspective that would gather history, nation and narration. The novel thus analyzed would reveal the specific 'idea 
of India' that the writer aims to depict and that would shape the literary in terms of the specific historical circumstances the subcontinent is undergoing because "this is a genre that began with an interest on how to read the past and continues to remain concerned with the question of 'the burden of history"' (Ghosh 312). Thus, in the anglophone Indian novel we can find a conversation between the present and the past that would hopefully allow for the future restoration of such a traumatic episode in the history of the subcontinent. In Priyamvada Gopal's words: "In its attempts to understand through reading the past, 'sufferings of the present', the anglophone novel is, finally, an engaged and dynamic participant in a conversation that is taking place across the literary spectrum of India" (187).

Following this train of thought, my aim in this article is to analyze in a diacronic perspective the novels of three Indian female authors: Sunlight on a Broken Column (1961) by Attia Hosain, Clear Light of Day (1980) by Anita Desai and An Unrestored Women (2016) by Shobha Rao, to emphasize this threefold perspective and to prove how female writing in English, in its evolution, becomes a tool to denounce, once more, the reality of women in India (Escobedo de Tapia 2018).

What is the role of women in the history of this event? How does history shape their stories? Where lies the link between history and memory? In fact, what are their stories?

Ethnicity, communalism, religious fundamentalism, cultural nationalism are issues inherent to the Indian subcontinent and they were anticipated by the religious-based division of the country caused by the Partition, which "posed the question of 'belonging", polarizing "choice and allegiance, aggravating old, and new, antagonisms" (Menon and Bhasin 21). The marginal place that women have historically, culturally and socially occupied in Indian society provides the background to the way women have given answers in their narratives to the questions previously posed. According to Joan Kelly, "women's history has a dual goal: to restore women to history and to restore our history to women" (9). So we will prove how the novels under analysis achieve the aim of "making women a focus of enquiry, a subject of the story, an agent of the narrative" (Wallacht Scott 36).

Traditionally, female Indian English writing has been the space where women have found their voice claiming for a redefinition of their identity, but above all this fiction represents the evolution of the social situation of women, which has always been linked to their historical circumstances. Female Indian writing in English has been diverse: from feminist and reivindicative, such as Nayantara Sahgal and Sashi Deshpande, whose creativity was based on political ideals and who searched for an identity in the past to redefine their present, to authors like Anita Desai in Fasting, Feasting (1999), who aimed to transcend time trying to find answers in the concept of a global human being. On the whole, their discourses of freedom are based on the development of three attitudes which are directly related to the context of India: taking conscience of an identity, searching for freedom in the domestic environment, and identifying themselves with Mother India; three generations of Indian women writing that represent the transition from a postcolonial discourse to a gender discourse. We identify thus an evolution of a feminist conscience from documenting reality through their novels to exploring that reality subtlety projecting 
new values and ideals. However their reality is, and has always been, a fragmented one and they seem to be entangled within psychological conflicts rooted in their own context and in the the clash with the progress brought about by the West. That is why we would find in this fiction female characters that search for their identity in their cultural roots. They represent a new class of women who moves between tradition and modernity and looks for a compromise with that new reality anchored in an image of freedom that seems to be veiled yet, as Anita Desai narrates beautifully in her short story "Winterscape" (Escobedo and De Quevedo 2018: 93-102).

Official records of the Partition appear to exclude women, but it is not due to the fact that they were absent from the event; on the contrary, no account of the horrors of Partition would be faithful to reality if it does not touch the violence that women experienced at that historical moment, because this goes parallel to the shock of Partition which, in fact, provides an opportunity to explain the representation of the language of aggression so "violence becomes a language that constitutes -and reconstitutes the subject" (Pandey 4).

Women were the silent subjects of the event and this is where Partition female fiction plays a role, because "Partition fiction has been a far richer source both because it provides popular and astringent commentary on the politics of Partition and because, here and there, we find women's voices speaking for themselves" (Menon and Basin 2).

The official historical records of the true stories of women seem to be unreliable data, and the written history of women simply non-existent. Grandmothers told their stories to their daughters and they transmitted them to their granddaughters. Contemporary female Indian English writing aims to restore the wreked history of women, and those stories that were part of the oral tradition seem to be given voice through female narratives. Female fiction pays homage to those hidden figures of history, and their memories from Partition aim to rehabilitate their stories since "in the history of any society, narratives of particular experiences of violence go towards making the community- and the subject of history" (Pandey 4).

These stories, as we shall see, are, intrinsically, narratives of loss: loss of homes, loss of friendships, loss of families, loss of love, and, most importantly, a profound loss of a sense of belonging; and in their loss, a shared destiny, as "accounts of history, of shared experiences in the past, serve to constitute these, their extent and their boundaries" (Pandey 4). And the same could be applied to stories. Female narratives of Partition aim to emphasize the chasm between history and memory, but with an aim for rehabilitation and restoration. Paradoxically, the Partition meant a world fallen apart, but for historians it signified the beginning of a new constitutional order and new political arrangements and, therefore, the survivors should start anew. That holocaust would bring about a reconstitution of community and history. Historical memory blends with private individual memories that ultimately shape the fictional stories of female experiences, depicting a period in the history of the nation that in turn represents the real situation of women in the Indian subcontinent.

In my analysis of the novels, I identify a threefold process regarding how the authors tackle the female experience of Partition: memories of rescue, memories 
of recovery and memories of rehabilitation, the same process undergone by many abducted and raped women during the Partition (Butalia 110). For this purpose, I will focus on the main female characters and how their identities and memories are construed in relation to the historical moment of Partition.

Sunlight on a Broken Column (1961) is considered an autobiographical novel, since Hosain had to face the fragmentation of her family due to Partition. She tells the story of an upper-class Muslim family in transition which goes parallel to the events that led to important changes in the nation. The story of this family represents the situation that many Hindu and Muslim families had to suffer at that historical moment. The story presents a first person narration by Laila, and the author weaves her individual story parallel to the political crisis that the nation was facing. However, the human story overtakes the political events, since the characters take part in the political affairs of the country. Twenty years are covered both of the family story and Indian history, from 1932 to 1952, and all throughout we observe the evolution of orphan Laila, who in turn epitomizes the evolution of women in the country. There is a temporal flow that brings the reader back and forth in time. The beginning of the story shows Laila having to face her grandfather's illness and death. We are told of the resultant changes that the domestic environment undergoes at the same time, since the lifestyle of the Zenana ${ }^{1}$ seems to start disappearing too. Memories here are of rescue, and the reader is told about ancestral traditions, family relations and tensions, peculiar relatives that come and go, weddings and funerals taking place. Laila is the subject of the story and would gradually evolve into an agent of the narrative. In the second part we find Laila facing a new life, since she moves to a different house and starts studying at university. Historical events seem to provoke a family turmoil, and the Taluqdars ${ }^{2}$ way of life seems to be shaken. Important changes are taking place in the family, the same as in society and the nation. Laila looks for and identity in the midst of this reality and in this second part her relationship with other characters is illustrative of how she gradually adopts an active role in the development of the narrative. We find in this part a Laila who seems to be torn between two worlds, the British and the Indian. She realizes that the world background she grew up in is in decline, but not much can be done except trying to adjust to changes. She belongs to the third generation of her family and stands as the image of a new young woman who has achieved education, but she still recalls the past times of her family almost in nostalgia. She tries to redefine her identity questioning basic principles on which her class had built up the social hierarchy, influenced by changes that are taking place and by the ideas of freedom and equality brought about by the western world. In this part, Hosain portrays a very realistic picture of the Indian society as well as the mayhem it faced at the height of the Indian Independence movement. Laila is torn between

1 The women's quarters, a secluded space.

2 The Taluqdars were Indian landholders during the Mughal Empire and the British Raj. They were in charge of collecting the taxes from a district. 
memories of rescue and memories of recovery. She is caught up in the confusion of whether to follow what she thinks is right or what society thinks appropriate: "some things never change. Obey your elders and do not hurt them. [...] You must learn that your 'self' is of little importance. It is only through service to others that you can fulfil your duty" (252). We observe at this moment a kind of rebellious attitude from a quiet and docile girl, as she asks: "but why should they hurt me?" (252). She had always been a troubled and thoughtful child, keeping her thoughts to herself. Laila is constrained by social rules but she believes in notions of love, equality and independence. The conception of love and marriage is an aspect worth highlighting. For other female characters like Zahra, marriage is a means to escape from the purdah culture and the strict discipline imposed on unmarried girls; individual happiness is relegated, for "what has love to do with marriage? It is like mixing oil and water. Love is antisocial, while matrimony preserves the world and its respectability" (296). Laila marries Ameer searching for completeness; she is truly in love with him. This is one of the most important aspects through which we observe the evolution of Laila, since marriage has always been a controversial issue as related to women's freedom in India. She rejects and even hates the sophisticated masks of high-class people, although she respects the old world and its ways. She has evolved into a logical and realistic young lady able to critically analyze important matters because education has enabled her to think and revise the old versus the new. Laila's fragmentation goes parallel to the effects that the Partition had on families like hers, fractured and divided by their beliefs and many of them forced to leave their native land looking for oportunities in a newly formed nation. Laila's assertion of her individual identity projects the freedom struggle the nation is undergoing. In this context, Laila represents a generation of young women immersed in confusion, troubled and fighting to make a place for themselves in a new changing country. This generation of women endured psychological violence, since they had to cope with the social rules of the times and their own individual desires as human beings, as when Laila's aunt disproves her views about a love story which pushed a Muslim girl to run away with a Hindu boy; Laila says: "after all, there have been heroines like her in novels and plays, and poems have been written about such love" (134). And her aunt answers, "Laila! I cannot imagine what has come over her. It is so unlike her. She is such a quiet girl. [...] I think you may go to your room now" (134).

The novel illustrates the Indian women of the 1930s and 1940s, victims as they were of the patriarchal system even within the domestic space, as we read about a group of five girls questioning life with the knowledge they acquire through literature, which has always meant a space of freedom for women:

The five of us spent as much time together as possible. When we were not arguing we were dissecting and questioning life, with the fear and the courage, the doubts and the certainty of inexperienced, questioning youth. Our world was bounded by our books, and the voices that spoke to us through them were great men, profound thinkers, philosophers and poets (128). 
Laila's evolution symbolizes the struggle for social freedom and the quest for her selfhood, despite the fact that "Attia Hosain indeed bares and exposes the limits of patriarchy that except domination it never knows anything else" (Kandhare 38).

In this novel, consequently, we find childhood memories of rescue and recovery before the arrival of the colonizer. The past is used by Laila to shape her identity in a changing present that apparently seems fragmented, just like the nation, but at the same time her memories of rescue allow for memories of recovery which turn into memories of restorarion and hope, since not only are we told about the wrongs, faults and cruelties of the society of the times of Partition and the effects it had on women, but we are also left with the celebration of the past, the feudal times, that somehow allows Laila to survive as the "new woman". Finally, if the Partition in this novel is shown as the agent of loss in many spheres of life, through the evolution of the female character of Laila we foresee a positive attitude towards the future, because the fact that she is able to decide her future means triumphing over the social world in which she lives, and thus the novel ends by emphasizing Laila's divided self:

I looked more closely at the face that stared back at me from the dusty mirror [...]. She was so different from me, that girl whose yesterdays and todays looked always towards her tomorrow, while my tomorrows were always yesterdays" (319).

In the second novel under scrutiny, Clear Light of Day (1980), the reader finds him/herself immersed within the flow of memories that Anita Desai outlines with her unmistakably poetic prose. The narrative flows between the past and the present: the 1930s, 1947 to 1948, and a few days in the 1970s, distributing the structure of the plot in four parts. Again, the story takes place within a domestic environment, this time in Delhi; and again the climax of the Das family story is set in times of the Partition of the nation. Memories here are linked to memories about the country. There are two main female characters, Tara and Bim: two women, two options, and two destinies that in the end converge. The novel starts with Tara revisiting the family home. After having left years ago to marry Kabul, a young diplomat, and having moved to the US, Tara returns home and reunites with her sister Bim, regaining her past at the same time. We perceive the house and the characters' feelings through her eyes. It is in the second part of the novel where the author weaves the plot through memories of rescue and recovery of a lost domestic realm. Precisely in this section coalesce the individual stories of these women and the history of the nation. Childhood memories of the past evoke happiness that contrasts with the events that took place in the summer of 1947, which consitutes, the same as in the previous novel, the background for the family fragmentation. The gradual disintegration of both the country and the family run parallel. Memories bring us back to the summer when their mother falls ill and dies, which somehow becomes a metaphor that implies the death of the Nation. It is in chapter Two where we most clearly identify the relationship established among history, nation and narration: 
Isn't it strange how life won't flow, like a river, but moves in jumps, as if it were held back by locks that are opened now and then to let it jump forward in a kind of flood? There are these long still stretches — nothing happens - ... and then suddenly there is a crash-mighty deeds take place... That summer was certainly one of them- the summer of ' 47 ' (42).

It is at this point that Bim refuses to ever marry and devotes herself to taking care of her aunt and brother. This shows the sacrifice of many women of the time who renounced their social destiny, matrimony, and they are further driven to the margins. However, she attends college and works as a teacher, bringing to the fore an image of an independent woman, but once more trapped in her destiny. Tara, on the contrary, stands as the image of a woman who manages to escape the social constraint of her native context; but the image that we get is that of a traitor almost, since she gets married but flees from India to the US. This contrast and division between the two sisters actually represents the division of the country. Memories of rescue and recovery seem to aim at remembering the times of school days, when the family was together, but they fail to find consolation, because the past is not comforting either, since memories are distorted. Remembrances of childhood do not really affect their freedom, nor mental or psychological stability, as opposed to another female character, Aunt Mira, who ends up committing suicide as a result of the recollection of memories from the past. The background here is the moment in which the Partition takes place; the nation breaks and Gandhi is murdered. The past seems to be shuttered and destruction comes about, since "there'll be more riots-killing- they'll slaughter every Muslim they can find- anywhere" (93); likewise, "the heat enclosed the house and all of them in it, sulphur-yellow in colour and tinged, like an egg-yolk, with blood" (96). From this point of the narrative on, it aims for rehabilitation. The female characters try to find the path for understanding their present lives. Memories of rescue and recovery have provided the clues for healing wounds, and in the last chapter the past, which meant destruction, reveals itself as preserver. Tara and Bim finally come to understand the past. They end up achieving freedom as human beings, finally re-discovering their true selves. Their feelings converge and they restore the past through love, which is the place where they finally find answers that gather them together. This stands as a metaphor used to remind us that the revision of past episodes like the Partition is mainly to restore the present and to avoid making the same mistakes, but above all love becomes the means by which we can prevent our destruction and the destruction of history: "to turn to the past means to take courage and face the truth in order to live with it. If people succeed in doing so, they will realize that life means love, love for others, not self-love which needs the applause of others" (Riemenschneider 58).

Finally, these women, through recovering memories from the past, ultimately achieve freedom, the same as the nation; but contrary to the aftermath of Indian Independence that gave way to violence and destruction, they foresee a clear future, since everything had been at last cleared out of the way: "there was nothing left in the way of a barrier or a shadow, only a clear light pouring down from the sun" (177). History, nation and narration meet; by remembering, women feel part 
of the history of their nation: "That soil contained all time, past and future, in it. It was dark with time, rich with time. It was her deepest self lived, and the deepest selves of her sister and brothers and all those who shared that time with her" (182).

The two previous novels analyzed tackle mainly the psychological aspects of women and use the Partition as the milieu of their recollections and as an excuse to show the social violence on women. An Unrestored Woman (2016), on the contrary, drives the reader into an overt context of gender violence and aggression against women. The title of the book is very significant, since the positive outlook on the future of women that we may infer from the narratives of the previous authors is clearly shuttered. The title explicitly reveals the real situation of women during Partition and the trauma of the event is the point of departure of the stories. The clear purpose of the author is to focus on the violence and horrors of the Partition on women. In the preface, the author immediately informs the reader about the brutalities inflicted upon women, and history, nation and narration are here intermingled; we cannot tell truth from fiction, and the narrative becomes almost a report of the violence that women suffered during the holocaust:

In 1988 a women's journal, Manushi, published a review of a Gujarati book, Mool Suta Ukhde (Torn from the Roots). [...] a sort of memoir and documentary account [...] they were forced to parade naked in the streets, others had their breasts cut off, their bodies were tattoed with marks by the opposing religion, they were forced to have sex with men of the other religion, many were impregnated. They bore children, often only to have them taken away forcibly. Sometimes families traded in their women, in exchange for freedom, at other times the women simply disappeared, abducted from camps, or as caravans of people marched across the border foot. But that hundreds, indeed thousands, of women had been subjected to rape, and abduction, was now clear"

(Butalia 132).

These are the real data of the horror and this is what we find in this collection of twelve stories. Rao seizes the event to show the situation of women in current India and Pakistan. As Butalia says, "history is a woman's body" (43), and, indeed, the writer enlightens this, driving us into desolation as we read her novel. History, nation and narration fuse, since the woman's body in her stories becomes the metaphor for the nation, whose innocence was once stolen and violated, such as in "The Opposite Sex" (Rao 123-142). Here the power of a cartographer enables him to win the love of a woman by drawing new borders that will cause suicide, murder and riots in the streets. We find wives abused, such as in "The Imperial Police" (41-59), whose protagonist, a Britih head constable, falls in love with a Sikh woman and gives evidence of the lack of communication and of how women fall victims to male desire. The widow is also represented, as in "The Merchant's Mistress" (17-40), where young Renu recalls: "it reminded her of standing with her husband, Gopichand, who'd been killed by a Muslim mob two years ago, on their scrubby acres of land, and gazing toward the blue and distant Shivalik Hills" (22). These memories of rescue and recovery do not allow her for rehabilitation though, for: 
Renu was nineteen when she left the refugee camp and traveled to Ahmedabad. It was the Winter of 1949. She'd been there two years, just long enough to understand that she, along with the eight hundred other widows stationed at the camp, had absolutely no future ahead of them (19).

The very first story, "An Unrestored Woman" (1-15), renders a profound sense of loss and a pessimistic stance. The story tells us about a girl who gets married when she is thirteen, becomes a widow two years later, and is witness to her mother-in-law's suicide. It is a story of dreams vanished and lost hopes of female freedom. Neela remembers trying to restore her present; she contemplates the branches of a banyan tree, symbol of the nation, and thinks "How long had it stood there? Maybe hundred of years. She thought of her mother and wondered whether she'd been cradled in her arms for even a moment before she'd died. She thought of her father"(15).

She thought and recalled, but "she felt her eyes warm with tears" (15), and looking back into the branches she felt they gathered to hold her and "held her as she had always dreamed of being held. As she would never be held again." (15). There is no hope. Women cannot trust the Indian nation.

Memories here do not aim for rehabilitation. In fact the stories portray real loss, because the aim of the writer is to show that women have not yet been restored. And will they ever be?

Especially significant is "The Lost Ribbon" (105-122), where we find the story of a Hindu woman who remembers her past when she was kidnapped and raped, and got pregnant, like many women during the times of Partition. She was fourteen then, and she had to decide whether to kill her child to keep her from the abductor's cruelty, or let her live out of her maternal instinct. Memory is essential in this story; remembrances of rescue and recovery allow her to review the trauma of this episode in her life, and she tries to overcome it in search of rehabilitation; because memory can be cathartic since, as she herself says, "it's funny though, the things we suffer and the things we remember about that suffering [...] that's how memory works, skips like a happy pebble, even if the memory is so very far from happy. Imagine if we remembered things exactly as they happened" (107). However, she clearly remembers: "and so I looked at you and I looked at you and I held you and then killed you. I killed you" (121). Finally, she realizes her lost innocence, just like the entire Indian nation: "what happened to that girl? The one who stood in the silence of a summer afternoon and felt her heart beating. Where is that girl? That heart?" (121). Dreams of childhood lost, dreams of a united nation vanished.

We follow some of the women across the Atlantic, maybe trying to escape their destinies, like Meena in "Unleashed" (61-79). But not even in their flee do they find rehabilitation, and this links with the last story, "Curfew" (221-238), where we find Rao's true message in the last words of the novel; Safia thought:

How long the journey, [...]. How far away that abode of peace. And yes, its door may close. Its lights may dim. And it may not even be for us to enter. But this, Safia thought -running and running and running- this is how you begin (238). 
In other words, Indian women's destiny (women's in general) means permanent escape, entangled in a circularity of time and history.

The narrative blends here with the actual historical records, which reveal that the recovery operation for abducted women continued over nine years after the Partition, and though 30,000 women were recovered, it gradually turned more difficult, since they were not willing to leave their children (born from rapes). Special homes were set up to allow them to make up their minds with no pressure, but "how much of a free choice this actually gave women, is another question" (Butalia 164).

As we have proved through this diacronic analysis, there is a clear evolution in the way Indian female authors tackle the theme of Partition, from the 1960s up to the contemporary times. The three examples stand denounce the 'truth,' and so the stories of women we read about tell us about the dark side of freedom which, if explored, inexorably reveals history itself. Thus, as we have seen in all the novels, history, nation and narration intermingle. Sunlight on a Broken Column and Clear Light of Day depict women psychologically affected by Partition. They are trapped in their domestic environment and silenced by the social constraints; they are women who feel identified with the Mother Nation in the transition from the colonial to the postcolonial, and in their fight for their Independence. Their stories are told through a subtle narration, making history almost elusive. On the other hand, $A n$ Unrestored Woman strikes us very straightforwardly, and aims to clearly show the violence suffered by women during Partition, to finally conclude that there is no hope, not even today. While the memories of rescue and recovery in the first two novels seem to search for sunlight towards a clear daylight finally turning into memories of rehabilitation, these are loudly vanished with the memories of rescue and recovery we identify in the last novel, which eventually aims to denounce that women are yet unrestored. Rao steps onto the other side of silence, and openly depicts the true stories of the hidden history of women at that historical moment, giving evidence that "the history of Partition was a history of deep violation-physical and mental-for women"(Butalia 131). The novel can be framed within the last trend of Indian female narratives which aim to make the world aware of the true reality of women in India, in an attempt to, hopefully, gain their space of freedom as human beings in the twenty first century, eventually restoring a sense of belonging lost in the midst of their stories all throughout history.

Furthermore, Attia Hosain, Anita Desai and Shobha Rao shape their narratives with a sense of loss, but their memories of rescue and recovery should remind us that revisiting the past, especially traumatic episodes like the Partition, should be central to find clues for understanding our present in an attempt to restore the errors committed by humankind, which also proves the evolution of Indian female writing from the postcolonial to the global and transnational, ultimately becoming transglobal. 


\section{REFERENCES}

Ahmed, Ishtiaq. The Punjab Bloodied, Partitioned and Cleansed: Unravelling the 1947 Tragedy Through Secret British Reports and First-Person Accounts. Oxford University Press, 2012.

Butalia, Urvashi. The Other Side of Silence: Voices from the Partition of India. Penguin Books, 1998.

Chester, Lucy P. Borders and Conflict in South Asia: The Radcliffe Boundary Commission and the Partition of Punjab. Manchester University Press, 2009.

Desai, Anita. Fasting, Feasting. Vintage, 1999.

_ Clear Light of Day. Vintage, 2001, [1980].

"Winterscape". Diamond Dust and Other Stories. Vintage, 2001.

Escobedo de TAPIA, Carmen. "Mujer y violencia en la literatura india: un clamor desde el silencio". Oceánide 10 (2018). Forthcoming.

Escobedo de TApia, Carmen and Verónica de Quevedo. Narrativa y cine de La India en lengua inglesa: una aproximación para la Era Global. Bohodón Ediciones, 2012.

Grosh, Amitav. The Iman and the Indian: Prose Pieces. Permanent Black, 2002.

Gopal, Priyamvada. The Indian English Novel: Nation, History and Narration Oxford University Press, 2009.

Hajari, Nisid. Midnight's Furies: The Deadly Legacy of India's Partition. Amberley Publishing, 2015.

Hosain, Atia. Sunlight on a Broken Column. Chatto \& Windus, 1961.

Kandhare, Ram S. "A Critical Study of Attia Hosain's Sunlight on a Borken Column”. The South Asian Academic Research Chronicle 2.8 (2015). http://www.thesaarc.com. Accessed 15 January 2018.

Kaushiк, Roy. "Partition of British India: Causes and Consequences Revisited". India Review 13.1 (2014), pp. 77-85.

Kelly, Joan. Women, History and Theory. Chicago University Press, 1984.

Menon, Ritu and Kamla Bhasin. Borders and Boundaries: Women in India's Partition. Kali for Women and Women Unlimited, 1998.

NaIr, Neeti. Changing Homelands: Hindu Politics and the Partition of India. Harvard University Press, 2011.

Pandey, Gyanendra. Remembering Partition: Violence, Nationalism and History in India. Cambridge University Press, 2001.

Rao, Shobha. An Unrestored Woman. Fleet, 2016.

Riemenschneider, Dieter. "History and the Individual in Salman Rushdie's Midnight' Children and Anita Desai's Clear Light of Day". Kunapipi. 6.2 (1984). http://ro.uow.edu.au/kunapipi/ vol6/iss2/10. Accessed 25 October 2017.

Von Tunzelmann, Alex. Indian Summer: The Secret History of the End of an Empire. Henry Holt and Company, 2007.

Wallach Scott, Joan. "Women's History and the Rewriting of History", in Christie Farnham, ed., Impact of Feminist Research in the Academy. Indiana University Press, 1987. 
